\title{
Analysis of the Performance of two Rangeland Protocols, Monitoring and Assessment
}

\author{
Soumana Idrissa ${ }^{1,2}$ \\ ${ }^{1}$ Faculté des Sciences Agronomiques, Université de Diffa, BP 78, Diffa, Niger \\ ${ }^{2}$ Institut National de la Recherche Agronomique du Niger (INRAN), BP 429, Niamey, Niger \\ Correspondence: Soumana Idrissa, Université de Diffa \& Institut National de la Recherche Agronomique du \\ Niger. BP 78, Diffa, Niger. E-mail: smaiga15@yahoo.fr
}

Received: April 28, 2016 Accepted: May 23, 2016 Online Published: May 25, 2016

doi:10.5539/jps.v5n2p47 URL: http://dx.doi.org/10.5539/jps.v5n2p47

\begin{abstract}
This study compared and contrasted data from the stick and modified Braun-Blanquet monitoring protocols in three areas with different land use histories: an unrestored barren area, a young and old restored areas. The study areas are part of extensive degraded of birch woodland and willow shrubland that have partly been re-vegetated.Vegetation and site characteristics were assessed in the three areas using the two protocols and soil sampling to characterize the ecological status of a land that has been re-vegetated. The analysis of the two protocols data indicates similar tendency which is the improvement of the ecological condition of the restored areas compared to the unrestored area. The soil carbon and nitrogen contents increased when the $\mathrm{pH}$ decreased with the restoration age. The improvement is better at the old restored area which has received more fertilization compared to the young restoration. Stick method estimated greater cover of vascular plants, litters, mosses and rocks, and lower amount of bare ground than modified Braun-Blanquet. The two protocols provided similar estimates cover of lichens and sedges. Stick method also provided three supplementary indicators which were not included in modified Braun-Blanquet: plants base, basal and canopy gaps. Another observation that could be proved by further studies, stick seemed to be more precise and economical than modified Braun-Blanquet. The indicators provided by the two protocols were related to the three attributes of ecosystems and the rangelands health indicators. This study is a preliminary that cannot be able to recommend one method, but it advocates stick method to assess and monitor vegetation dominated by herbaceous layer as grassland and modified Braun-Blanquet for the one dominated by woody layer.
\end{abstract}

Keywords: rangeland ecology, restoration, protocol, biodiversity, resilience, Iceland

\section{Introduction}

Monitoring biodiversity and detecting changes on natural resources are often been quantified by collecting data on vegetation composition and structure. Assessing plant composition and structure is necessary, but not enough to predict long-term resilience (Herrick et al., 2006b). Since ecosystem resilience depends on the functioning of ecological processes, it is crucial to base the assessment on them. However, directly assessing ecological processes is difficult due to their complexity and the interactions among them (Pellant et al., 2000). For that reason, simple indicators that relate ecological processes have been developed for monitoring rangeland condition (Ludwig et al., 2004). The typical example of indicators is the “ Indicators of Rangeland Health' (IRH) developed by the United States land management agencies within a protocol titled 'Interpreting Rangeland Indicators Health" to assess rangelands condition (see Pellant et al., 2000, 2005; Pyke et al., 2002; Herrick et al., 2006a; Herrick et al., 2006b; Herrick et al., 2012). In this protocol, 17 indicators of plants cover and diversity, soil, water component, etc., are used to assess three ecosystem attributes on which all lands use depend: Site and soil stability, hydrologic function, and biotic integrity (Toevs et al., 2011). Soil and site stability refers to the capacity of a site to limit redistribution and loss of soil resources (e.g. nutrients and organic matter) by wind and water. Hydrologic function is the capacity of a site to capture, store, and safely release water from rainfall, run-off, and snowmelt. Biotic integrity is defined as the capacity of a site within an ecosystem to support natural processes within a normal, or expected, range of variability. Collectively, these three attributes define rangeland health, i.e., how ecological processes (water cycling, energy flow, and nutrient cycling) are functioning within a normal range of variation to support specific plant and animal communities. In practice, quantifiable biological 
and physical components of ecosystems that are correlated to those attributes are assessed as indicators of ecological processes and site integrity. Biological components of ecosystem include plants cover and composition, functional groups cover and composition, biological crusts, etc. The physical components of ecosystems consist of percentages of bare ground, rocks, etc. Several protocols including modified Braun-Blanquet and line-point intercept methods or recently "stick method", give measures that are used as indicators of some ecosystem attributes (Pellant et al., 2000; Ludwig et al., 2004; Tongway \& Hindley 2004; Herrick et al., 2005; Pellant et al., 2005; Riginos \& Herrick 2010). The modified Braun-Blanquet protocol for sampling vegetation is adapted from the Zurich -Montpellier school of phytosociology, one of the classic methods of studying vegetation (Braun-Blanquet, 1932). Braun-Blanquet protocol, even if it has been challenged to be subjective (Egler, 1954), the approach is still widely used and is argued to represent scientifically sound, versatile and efficient assessment method in botany (Werger, 1974). It is developed to identify and describe plants communities, used to monitor effects of changes on plant species within these communities, and to assess restoration or reclamation success of disturbed plant communities (Bonham et al., 2004). The "stick method" is a modification of the line-point intercept method, developed in context with a monitoring tool for rangeland assessment (see Riginos \& Herrick, 2010). This protocol is suggested for rangelands assessment, it seems to be precise, easy to learn and to apply, and provide easily attributes that relate to productivity, infiltration or runoff and soil loss. Different studies have been carried out to describe several assessment protocols and show their strengths and weaknesses (Stohlgren et al., 1998; Prosser et al., 2003; Anderson \& Fehmi, 2005; Carlsson et al., 2005; Godínez-Alvarez et al., 2009), additionally this study proposed to determine the differences between the protocols described above and how the indicators they provided can be linked to the ecological status of a given land.

This study intends to compare the two protocols, the stick method and modified Braun-Blanquet, for assessing the ecological status of a land that has been revegetated. Specifically, the purposes of the study is to: (1) compare and contrast the two monitoring protocols in three areas with different land use histories: an unrestored barren area, young revegetated area and old revegetated area, located within the same ecological site, (2) assess the succession trend in the three areas; (3) relate the indicators provided by the two protocols to the three key attributes of ecosystem and the Rangeland Health Indicators (RHI) for interpretation; (4) and evaluate the relevance of these simple indicators for sustainable land management.

\section{Material and Methods}

\subsection{Study Area}

The study was conducted in southern Iceland (Figure 1), $20 \mathrm{~m}$ above sea level, at three areas, with similar environmental characteristics and different land use histories: (1) unrestored area and (2) young restoration area (three years old) located at Varmadalur, and (3) old restoration area (seven years old) located at Selalækur (Figure 2). The climate of southern Iceland close to the study area is oceanic-boreal with a mean temperature from 1990 to 2004 of $-0.97^{\circ} \mathrm{C}$ in January and $11.3^{\circ} \mathrm{C}$ in July, and a mean annual precipitation of $970.38 \mathrm{~mm}$ (Icelandic Meteorological Office, unpublished data from Hella weather station). The soils of Iceland, mostly Andosols (WRB; Vitric Andosol) or Andisols (Soil Taxonomy; Vitricryand), formed on volcanic deposit lava were exposed to wind and water erosion (Arnalds et al., 2001, 2013). The study sites are part of extensive degraded areas that have partly been revegetated. The cumulative effect of natural disturbances such as the cooling weather, the active volcanos, increased aeolian deposits; and human activities like deforestation, overgrazing added to the susceptibility of the soil to erosion, amplified the degradation (Arnalds, 2000). The nearby Hekla volcano is very active. It has erupted 20 times in historical times, producing both tephra and andesitic lava flows and has occasionally strewn tephra over the study area (Elmarsdottir et al., 2003). The history of the study area probably resembles that of large areas in Iceland where wood gathering and heavy grazing has destroyed native birch woodlands and willow shrublands. The soil surface of the study area is typical gravelly sand classified as lag gravel (Arnalds et al., 2001). The lag gravel soil, seem to result, from the degradation of the birch woodlands and willow shrublands, which were the original vegetation of Iceland at the time of settlement (Gunnlaugsdottir, 1985). Restoration actions started at southern Iceland about 100 years ago with the objective to increase vegetation cover on eroded areas and improve the pasture for grazing animals by fencing and aerial sowing grass. Treating degraded land with fertilizers, were initiated about 60 years ago with a rate of about 100-150 kg N ha ${ }^{-1}$ year $^{-1}$ (see Elmarsdottir et al., 2003; Gretarsdottir et al., 2004). In this study, treatment were done by application of about $200 \mathrm{~kg} / \mathrm{ha}$ of inorganic NP (25: 6). The three years old restored area had received three applications of fertilizer and the seven years old restored area four applications. 


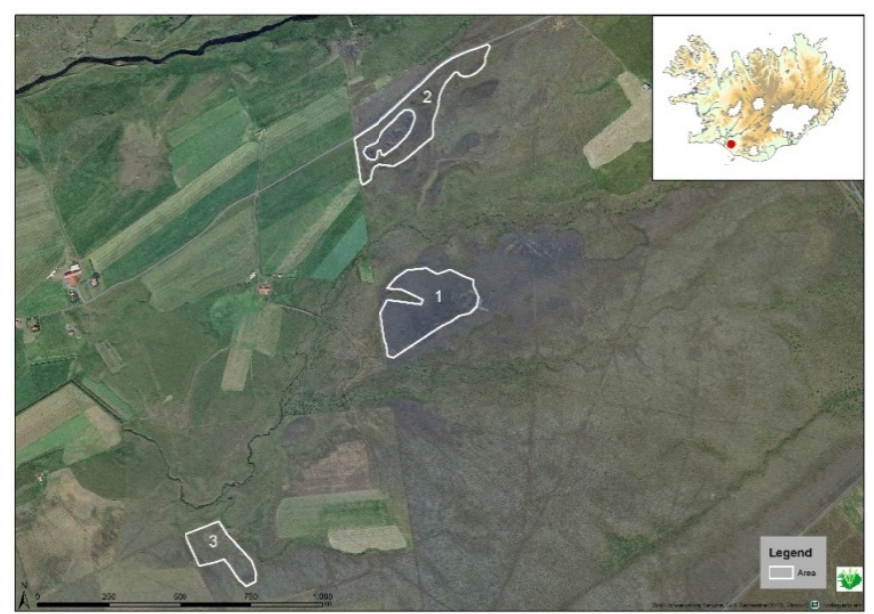

Figure 1. Location of the study in south Iceland; $1=$ unrestored area, $2=$ young restored area ( 3 years) and $3=$ old restored area ( 7 years)
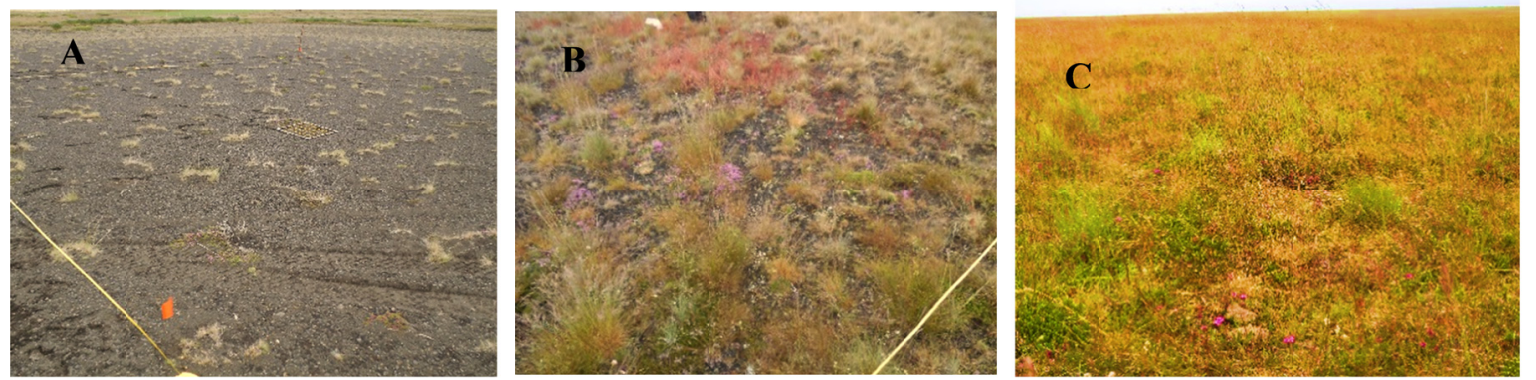

Figure 2. Cover of plants and bare ground at the three study areas: $\mathrm{A}=$ unrestored area, $\mathrm{B}=$ young restored area (3 years) and $\mathrm{C}=$ old restored area (7 years). (Photos: I. Soumana, 9-12 July 2013)

\subsection{Sampling Design}

Vegetation and site characteristics were assessed at four randomly selected points in each area. From each pre-determined point, four transects of $25 \mathrm{~m}$ were established in the direction of the four cardinal points for vegetation and sites characteristics surveying using the "stick method". At each pre-determined point, a $10 \mathrm{~m} \times$ $10 \mathrm{~m}$ plot was established, in the north-east quadrant. Five $0.25 \mathrm{~m}^{2}$ quadrats were randomly selected within the plot, for vegetation and sites characteristics surveying using modified Braun-Blanquet (Figure 3).

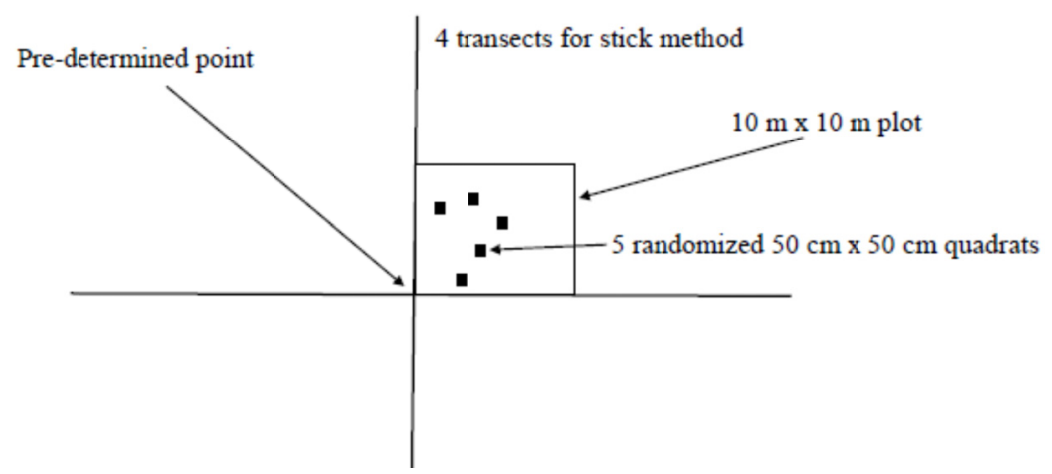

Figure 3. Placement of the transects for "stick method" and the $10 \mathrm{~m} \times 10 \mathrm{~m}$ plot for modified Braun-Blanquet relative to each of the predetermined points 


\subsection{Sampling Vegetation and Site Characteristics with "Stick Method"}

Along the four transects of each pre-determined point, a stick of one meter, was laid systematically on the ground at every five meters for recording vegetation and environmental variables. Foliar cover of plants functional groups along the $1-\mathrm{m}$ stick by dropping a metal rod of one mm diameter vertically towards the soil at every $20 \mathrm{~cm}$ and all shrub, grass, forb, sedge, moss and lichen, contacted by the rod were recorded, for a total of 25 points/transect and 100 points/predetermined point. At the soil surface, contacts of the rod with plants base, litter, bare ground and rock; and base and canopy gaps through the stick were recorded. The total height of the vegetation which covers the stick, was also estimated visually Plant bases are places where plants are rooted to the ground, it reduced soil erosion by slowing water flowing. When plants are not close together, there are gaps either between plants base or between plants canopy that allow water and wind to pick up enough speed to carry away the soil (see Riginos and Herrick, 2010).

\subsection{Sampling Vegetation and Site Characteristics with Modified Braun-Blanquet}

Braun-Blanquet five levels of abundance have subsequently been modified into six, eight or ten levels by splitting one, two or three scales in order, to improve the accuracy of the estimated data (Daubenmire, 1959; van der Maarel, 1979). In this study, plants functional groups were estimated in the quadrats of $0.25 \mathrm{~m}^{2}$ using the following eight cover classes: $1=<1 \% ; 2=1-5 \%, 3=6-10 \% ; 4=11-15 \% ; 5=16-25 \% ; 6=26-50 \% ; 7=$ $51-75 \%$; and $8=76-100 \%$. The cover of total plants and other vegetation, percentages of bare ground, rock, litter and the height of the tallest branch were also recorded. The two protocols provide measurement of similar indicators, but Modified Braun-Blanquet does not include measures of plants base, basal and canopy gaps offered by the stick method.

\subsection{Soils Sampling}

Soils surface layer were sampled in the centre of each $0.25 \mathrm{~m}^{2}$ quadrat, with an auger, to the depth of five $\mathrm{cm}$, and then the five samples from each quadrat were mixed to make a composite sample. Soils were dried at $30^{\circ} \mathrm{C}$ and passed through a $2 \mathrm{~mm}$ sieve to prepare them for analysis. Furthermore, the soil samples were checked for moisture content at the time of analysis for adjusting results. Total carbon $(\mathrm{g} / \mathrm{kg})$ and nitrogen $(\mathrm{g} / \mathrm{kg})$ contents were determined by dry combustion using Vario Max C/N-Macro Elemental Analyser. Soil pH was measured with electrodes in a 1:5 soil-water suspension (Blakemore et al., 1972).

\subsection{Data Analysis}

Statistical analysis was done on the mean cover of total vascular plants, functional groups, litter, rocks, bare ground, plants base and basal gaps recorded in the three treatments. Before analysis, the cover scores from modified Braun-Blanquet were transformed to percentages by using the central value of each cover class and averaged over all the five quadrats of each $10 \mathrm{~m} \times 10 \mathrm{~m}$ plot (cf Aradottir, 2012). The amount of shrub, grass, forb, sedge moss and lichen, base, litter, bare ground, rock, base and canopy gaps recorded on transects by the stick, were also averaged for each pre-determined point. Thus, there were four data points for each protocol in each area (treatment), for a total of 12 points. The pooled data from the two protocols was used to test for effects of assessment protocol, restoration age (treatment) and their interaction by analysis of variance (ANOVA, Generalized Linear Model) where restoration age was nested within the sample areas. The relationships between measurements by the two protocols were also analysed using the correlation of Pearson (r). For the using of Analysis of Variance (ANOVA) and Pearson Correlation, the normalities of the pooled data were tested by using the test of Kolmogorov-Smirnov. When the normality and equal variances were not met, the data were $\ln (x+1)$, $\operatorname{lnx}$, square-root or ASINH transformed. Transformation by $\ln (\mathrm{x}+1)$ was used for amount of rock and bare ground, lnx for litter cover, square-root for sedge cover and ASINH for moss, lichen, grass, forb and shrub covers. One way ANOVA was used to test the differences of soil $\mathrm{pH}$, total nitrogen and carbon contents, and $\mathrm{C} / \mathrm{N}$ ratio among treatments (restoration ages). The ANOVAs, normality and correlation tests were done with Minitab v.14. (Dytham, 2011). Principal Component Analysis (PCA), a multivariate test which weights the variables to maximize the variance of the response variable (Dytham, 2011), was used to visualize the differences between the two protocols in ordination space. PCA was also done separatly on the two data sets, to observe how well they reflect difference in functional groups cover and composition, and changes in site characteristics.In the PCAs, cover of grass, forb, sedge, moss, shrub and lichen were used as variables of abundance. The PCAs were done using PC-ORD v.5.0 (McCune \& Grace, 2002). 


\section{Results}

\subsection{Variation of Functional Groups Abundance and Site Characteristics with Increased Restoration Age and Between Protocols}

GLM analysis done on the pooled data revealed significant effects of protocol types, restoration ages and their interaction for cover of total plant, rock, bare ground, moss, litter, grass, forb and shrub (Figure 4). Modified Braun-Blanquet protocol significantly gave lower cover of total plant, rock, moss, litter, grass, forb and shrub for all the treatments $(p<0.001)$ compared to the stick method. On the other hand, stick method gave significantly lower cover of bare ground for all the three treatments $(\mathrm{p}<0.001)$ compared to the modified Braun-Blanquet. In contrast, there were no significant effects $(p>0.05)$ of protocols, restoration ages, and their interaction for cover of lichen and sedge excepted for lichen, which showed only significant effect for restoration ages $(p=0.006)$. In fact, for all the treatments, stick method seemed to capture more vegetation, plants functional groups, rock, and litter; and modified Braun-Blanquet appeared to detect high cover of bare ground. Compared to the unrestored area, the two protocols revealed significantly higher cover of total plants, moss, litter, grass, forb, lichen and shrub; and significantly lower cover of bare ground and rocks at the restored areas with increased age of the restoration treatment. Only the cover of sedge was not different between the three areas and the two protocols. In fact, despite the variation of cover estimates of plants and site characteristics, the two protocols showed similar tendencies.
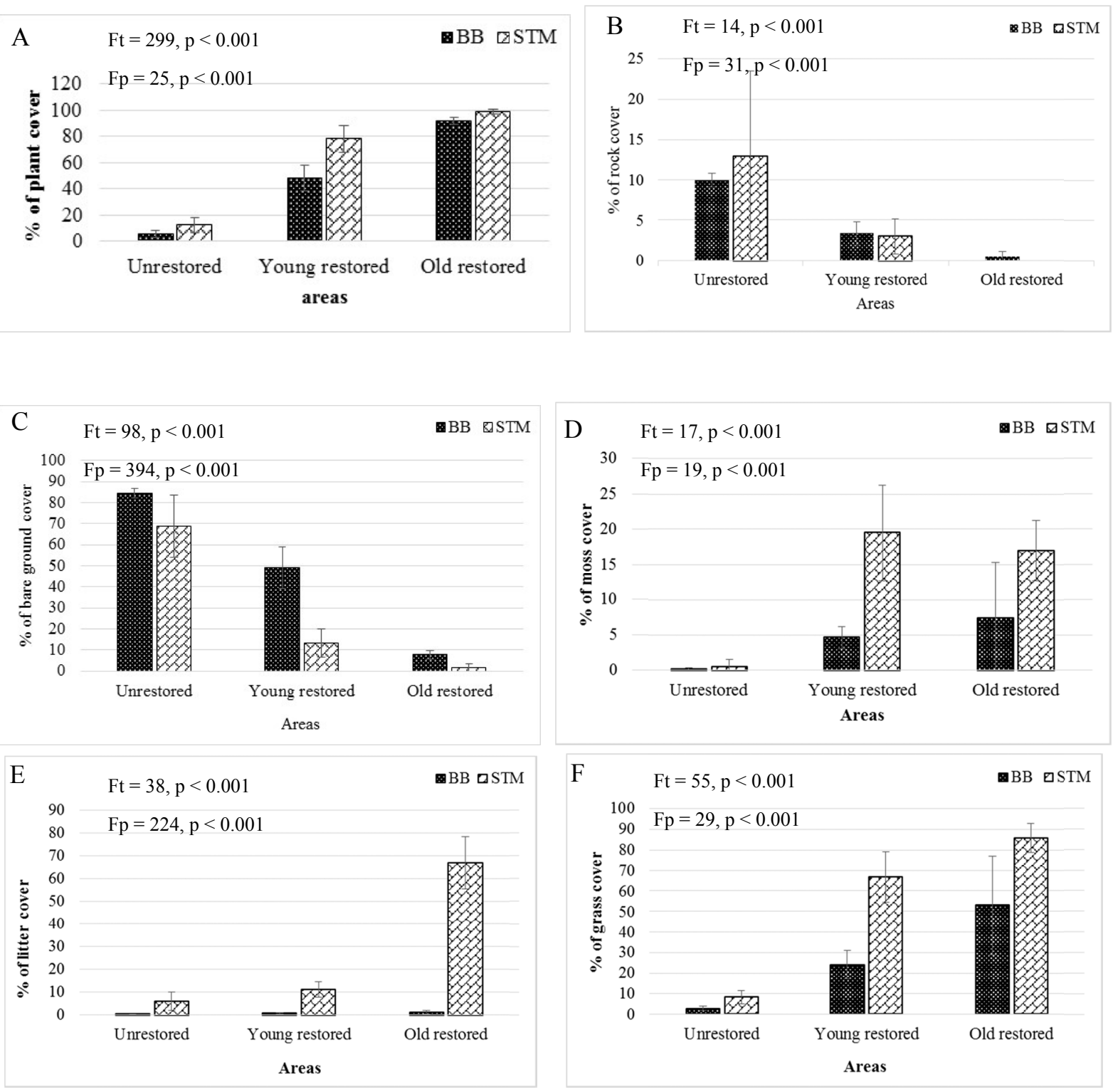

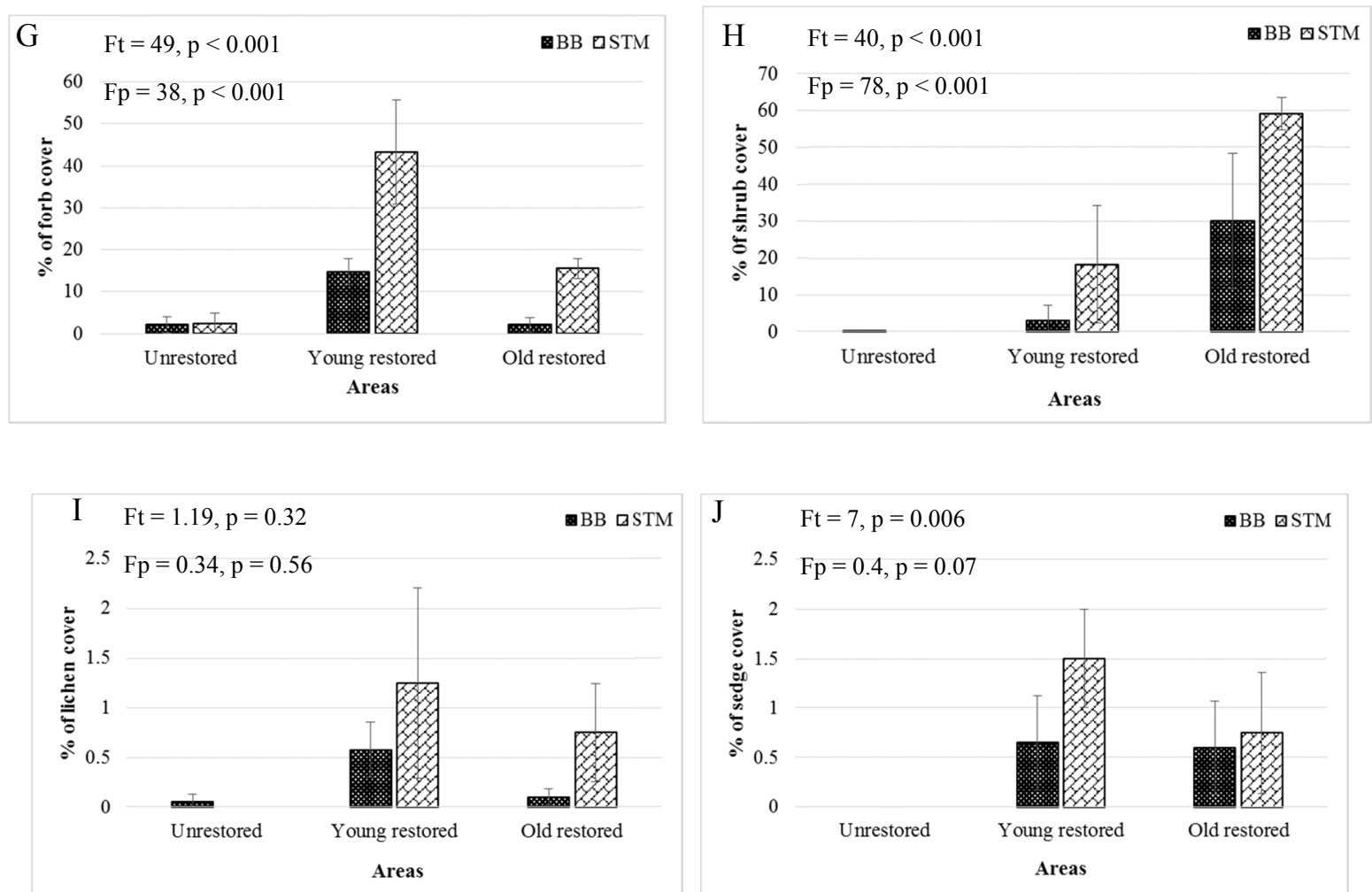

Figure 4. Estimated cover (mean and standard error) of (A) total plants, (B) rocks, (C) bare ground, (D) moss, (E) litter, (F) grass, (G) forb, (H) Shrub, (I) sedge and (J) lichen in different study areas for stick method (STM) and modified Braun-Blanquet protocol (BB)l. Results from nested ANOVA on protocol types (Fp), restoration (treatments)(Ft) and their interaction $(\mathrm{Ft} \times \mathrm{Fp}$ ) for each cover $(\mathrm{A}-\mathrm{J})$. When $\mathrm{P}<0.05$ the effect is significant

\subsection{Effects of Restoration Activities on the Land}

The two first axis of the PCA ordination of pooled data from stick method and modified Braun-Blanquet assessment explained cumulatively $86.81 \%$ of the variance (Figure 5). In the graph, only plots recorded in the unrestored area were located in the same place, the other plots were scattered in the ordination space. Thus, data from the unrestored and restored areas showed respectively high homogeneity and variability of vegetation cover with samples, between treatments and protocols.

Axis 1 of the two PCAs of the stick method and Modified Braun-Blanquet when analysed separately (Figure 6) explained respectively 61 and $36 \%$ of the total variances. The two graphs revealed similar tendency, plots from restored areas versus the unrestored area were separated along axis 1 , and reflected distinctly a recovery gradient. Analysis of the data from the stick method PCA (Figure 6A), showed strong positive correlations between axis 1 and total plant cover, height, plants base, litter, carbon, nitrogen and $\mathrm{C} / \mathrm{N}$ ratio. Strong negative correlations were observed between the same axis and rocks, bare ground, basal gaps and $\mathrm{pH}$. Similar correlations were observed between factorial axis and environmental variables in the modified Braun-Blanquet PCA (Figure 6B). Axis 1 of the both ordinations was interpreted as a gradient of recovering plants cover, height and base, carbon and nitrogen contents, $\mathrm{C} / \mathrm{N}$ ratio and litter; and reducing $\mathrm{pH}$, rocks, and bare ground. 


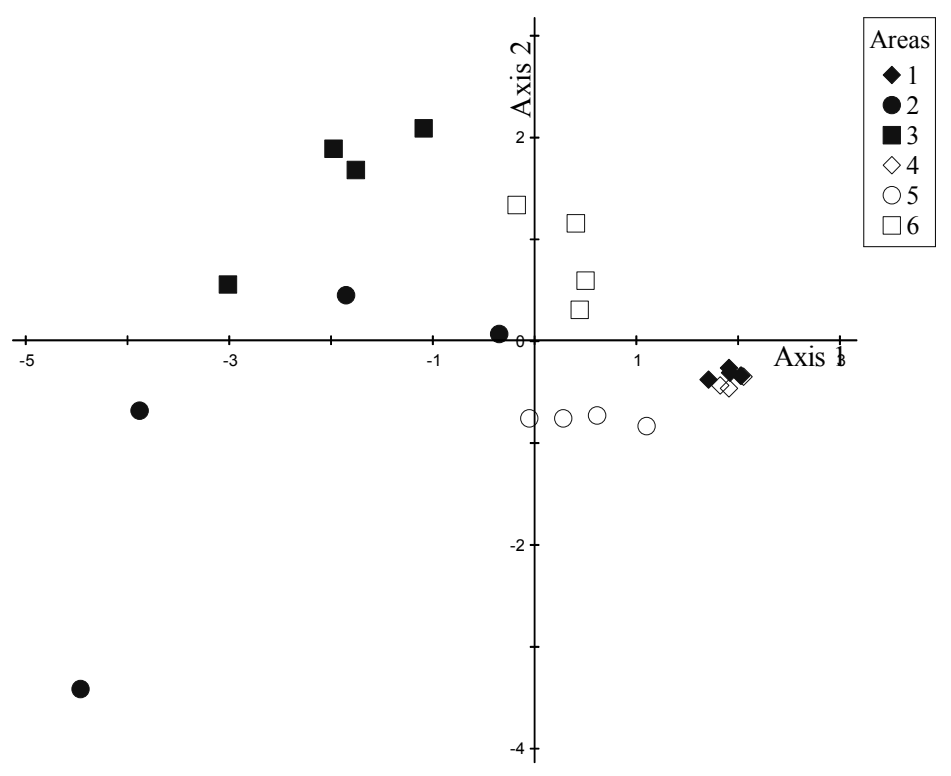

Figure 5. Principal components ordination from pooled data, stick method (filled plots) and Braun-Blanquet (empty plots), diamonds = unrestored plots, circles $=$ yound restored plots and boxes $=$ old restored plots;

Eigenvalue and variance of axis 1 are respectively 0.79 and $61 \%$, and eigenvalue and variance of axis 2 are 0.12 and $21 \%$

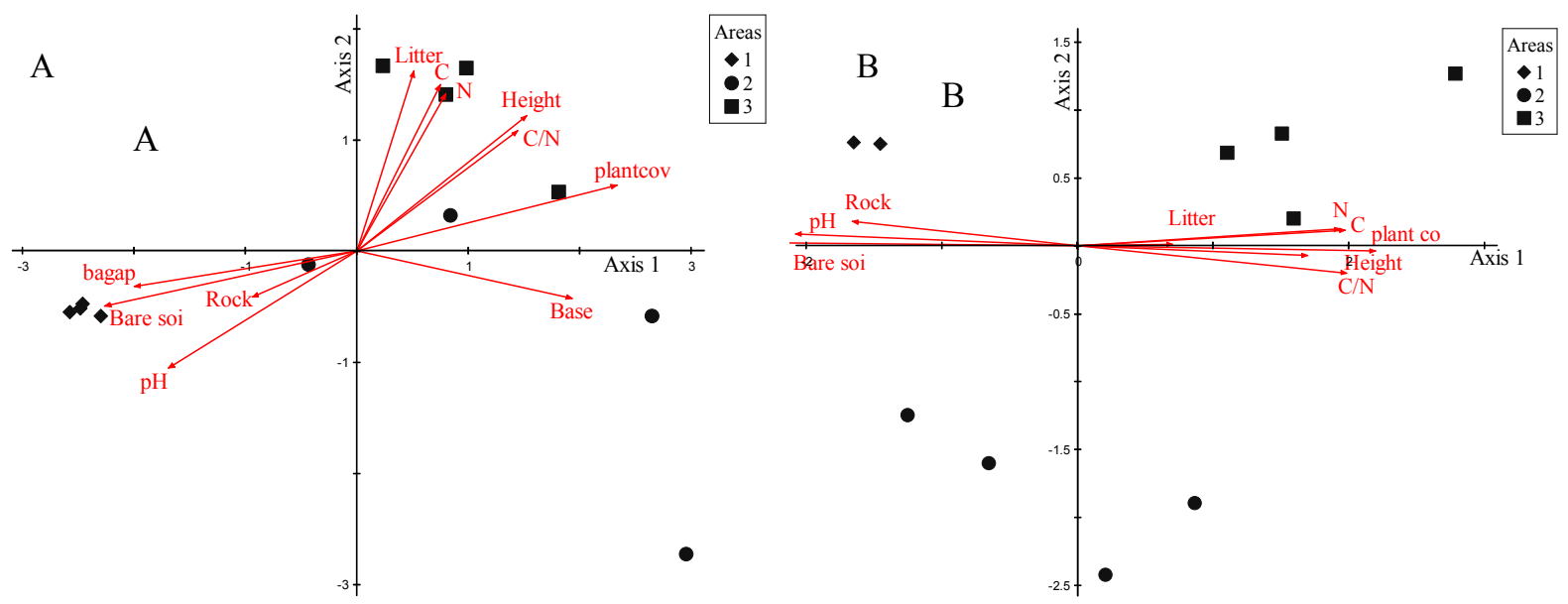

Figure 6. Principal components ordinations of stick method and modified Braun-Blanquet data: graph A = PCA with stick method; graph B = PCA with modified Braun-Blanquet; diamonds = unrestotred plots, circles = yound restored plots and boxes = old restored plots; Graph A: Eigenvalue and variance of axis 1 are 0.79 and $63 \%$, and eigenvalue and variance of axis 2 are 0.19 and 31\%; Graph B: Eigenvalue and variance of axis 1 are 0.71 and $36 \%$ and eigenvalue and variance of axis 2 are 0.24 and $29 \%$. Plantcov $=\%$ of plants cover, height $=$ height of plants (cm), $\%$ of plants base, $\mathrm{C}=$ soil surface carbon content, $\mathrm{N}=$ soil surface nitrogen contents, $\mathrm{C} / \mathrm{N}$ ratio, litter $=\%$ of litter cover, rocks $=\%$ of rocks cover, Bare soi $=\%$ of bare ground cover, bagap $=\%$ of basal gaps

\subsection{Comparison of the two Protocols}

Strong correlation was observed between the stick method and modified Braun-Blanquet protocols for cover of total vegetation $(r=0.95)$, rocks $(r=0.86)$, bare ground $(r=0.91)$, moss $(r=0.87)$, grass $(r=0.93)$ and forb $(r=$ 0.73). On the other hand, there was no relationship between the protocols for cover estimates of shrub, sedge, lichen and litter. Comparison between the stick method and modified Braun-Blanquet protocols (Figure 7) showed only similar cover estimates of sedge and lichen. Stick method gives higher cover values of total plant, rocks, grass, moss, litter, forb and shrub than modified Braun-Blanquet. On the other hand, modified Braun-Blanquet tended to estimate higher bare ground cover than stick method. 

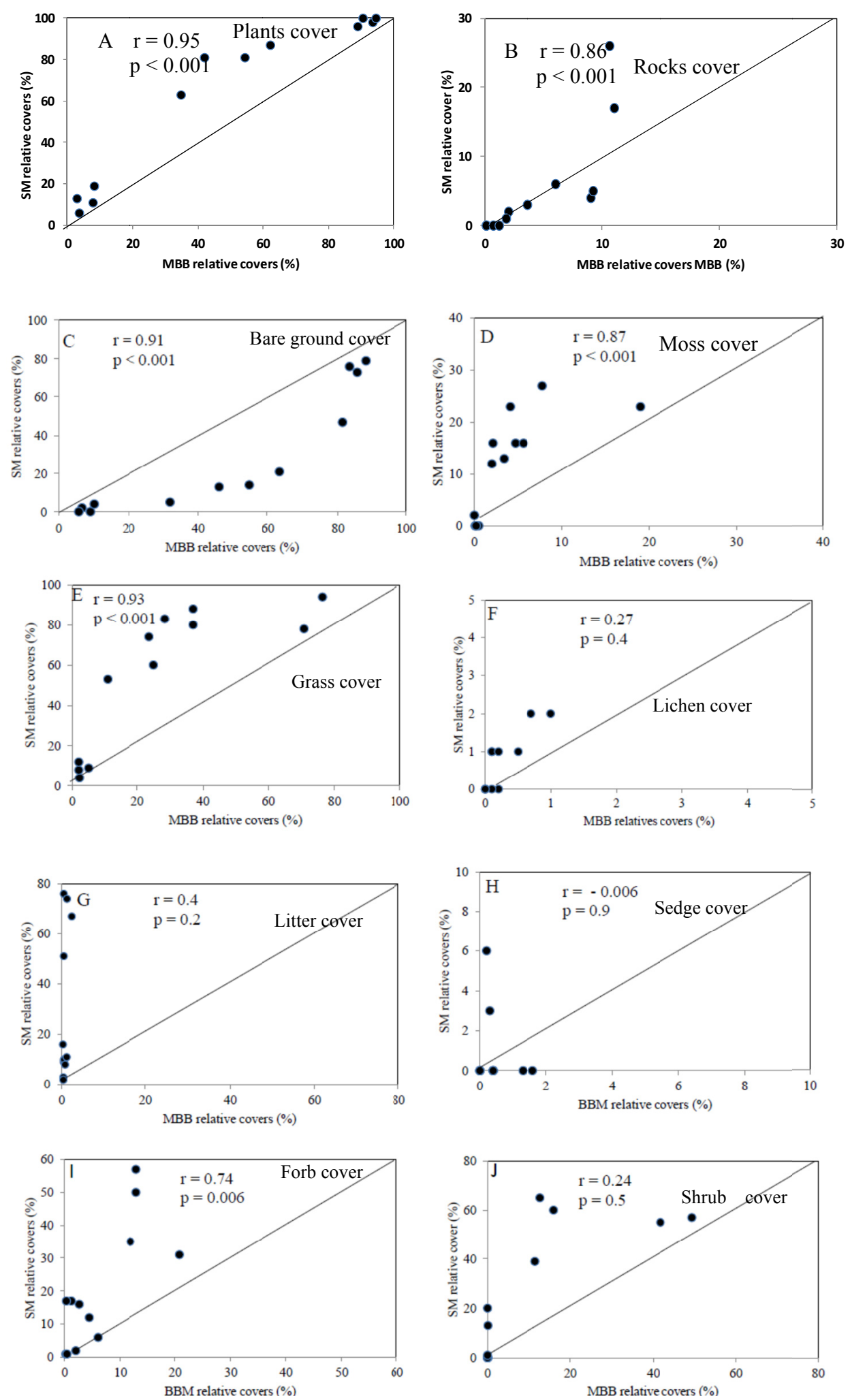

Figure 7. correlation of Person (r) between average cover per point measured by the stick method (SM) and the average cover per point for the modified Braun-Blanquet (MBB) protocol for (A) Total plant cover, (B) Rock, (C)

bare ground, (D) moss, (E) grass, (F)lichen, (G) litter, (H) sedge, (I) forb and (J) shrub; when p $<0.05$, the correlation is significant 


\subsection{Effects of Restoration Activities on Soil Surface Properties}

Compared to the unrestored area, soil carbon $(\mathrm{C})$ and nitrogen $(\mathrm{N})$ contents and the $\mathrm{C} / \mathrm{N}$ ratio increased significantly with restoration ages while $\mathrm{pH}$ decreased significantly with restoration ages $(\mathrm{p}<0.001)$ (Figure 8$)$.
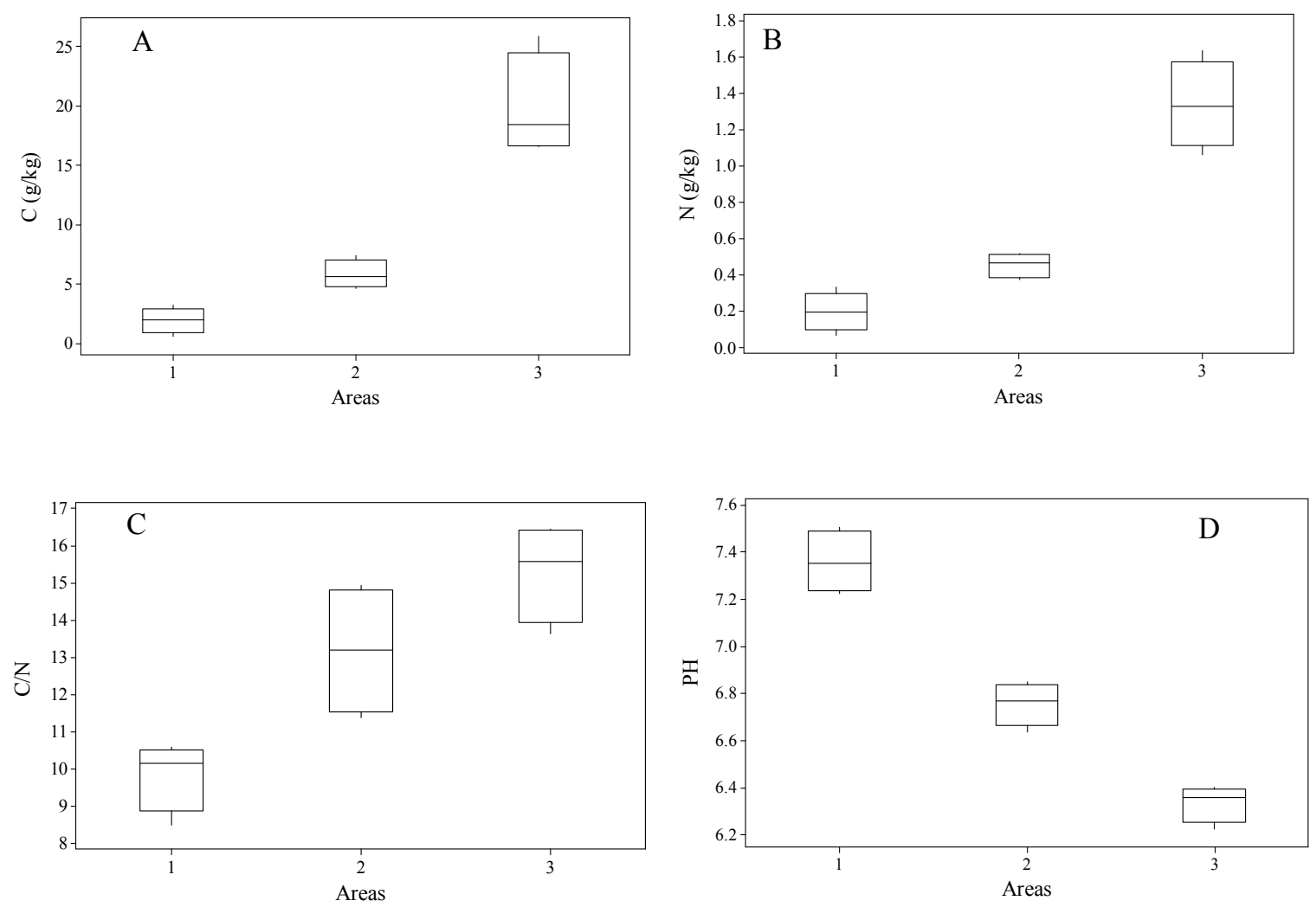

Figure 8. Variation of soil properties shown in box plots between the three areas; $1=$ unrestored, $2=$ young restored, 3 = old restored; Carbon (A), Nitrogen (B), C/N ratio (C) and $\mathrm{pH}(\mathrm{D})$; dash in box = median; the interquartile range $=$ minimum and maximum

\section{Discussion}

\subsection{Successional Trend and Interpretation of the Quantitative Indicators}

Compared to the unrestored area, the restored areas condition was changed by the restoration action, which led to increase cover of vascular plants, lichen and moss, plants base, litter, soil carbon and nitrogen contents, and C/N ratio; and decrease cover of bare ground, rocks, basal gaps and soil $\mathrm{pH}$. When the carbon and the soil contents were increasing with the restoration age in the restored areas, the $\mathrm{pH}$ was decreasing. The quantitative indicators showed the recovery of the fertilized areas. The differences between the three areas could be attributed to the age of restoration and the number of fertilizer applications. The abiotic and biotic conditions of the unrestored area can also constrain seedling survival and plants growth (Elmarsdottir et al., 2003). Fertilization may remove the constrained by improving the soil fertility at the restored areas. This may enhance the stability and the hydrological functions of the soil. Stabilized and high infiltrated soil could facilitate the turnover and the establishment of the plant species that increase plants productivity through the availability of safe microsite and the capture of wind-blown seeds (Gretarsdottir et al., 2004). Plants biomass production may increase foliar cover of vascular plants and base, and litter production that reduce the surface of bare ground and the amount of rocks. The enhancement of foliar cover of vascular plants can create a microclimate that can allow the establishment and the expansion of the understorey layer such as lichen and moss. 
Table 1. Assessment protocols, quantitative indicators, keys attributes of ecosystems, and Rangeland Health Indicators (RHI) (Pellant et al. 2005; Riginos \& Herrick 2010); HF = hydrological functional, SS = soil stability, $\mathrm{BI}=$ biotic integrity

\begin{tabular}{|c|c|c|c|c|c|c|c|}
\hline \multirow{3}{*}{$\begin{array}{l}\text { Assessment protocols } \\
\text { Quantitative Indicators }\end{array}$} & \multicolumn{6}{|c|}{ key attributes of ecosystems } & \multirow[b]{3}{*}{ Rangeland Health indicators } \\
\hline & \multicolumn{3}{|c|}{ Stick method } & \multicolumn{3}{|c|}{$\begin{array}{c}\text { Modified } \\
\text { Braun-Blanquet }\end{array}$} & \\
\hline & $\mathrm{HF}$ & SS & $\mathrm{BI}$ & $\mathrm{HF}$ & SS & $\mathrm{BI}$ & \\
\hline $\begin{array}{l}\text { \% Total vascular plants } \\
\text { cover }\end{array}$ & $\sqrt{ }$ & & $\sqrt{ }$ & $\sqrt{ }$ & & $\sqrt{ }$ & $\begin{array}{l}\text { Bare ground, Annual production, gullies, plant mortality, number of } \\
\text { function groups, plant communities, water flow }\end{array}$ \\
\hline$\%$ bare ground & $\sqrt{ }$ & $\sqrt{ }$ & & & $\sqrt{ }$ & $\sqrt{ }$ & $\begin{array}{l}\text { Rills, water flow, pedestals, gullies, wind-scoured areas, blowouts or } \\
\text { deposition areas, litter movement, bare ground, soil resistance to erosion, } \\
\text { soil loss and compaction layer, litter movement }\end{array}$ \\
\hline$\%$ plant Base & $\sqrt{ }$ & $\sqrt{ }$ & & & & & $\begin{array}{l}\text { Soil resistance to erosion, soil loss, invasive plant, compaction layer, } \\
\text { litter amount, annual production, invasive plant, reproductive capability } \\
\text { of perennial plants. }\end{array}$ \\
\hline$\%$ Litter & $\sqrt{ }$ & $\sqrt{ }$ & $\sqrt{ }$ & $\sqrt{ }$ & $\sqrt{ }$ & $\sqrt{ }$ & $\begin{array}{l}\text { Soil resistance to erosion, soil loss, compaction layer, plant mortality, } \\
\text { litter amount, annual production, plant mortality, litter amount, } \\
\text { productivity, invasive plants, reproductive capability of perennial plants. }\end{array}$ \\
\hline \% Rock & $\sqrt{ }$ & $\sqrt{ }$ & & $\sqrt{ }$ & $\sqrt{ }$ & & $\begin{array}{l}\text { Water flow, pedestals, bare ground, wind-scoured areas, blowouts or } \\
\text { deposition areas, soil resistance to erosion, soil loss and degradation }\end{array}$ \\
\hline \% Basal gaps & $\sqrt{ }$ & $\sqrt{ }$ & $\sqrt{ }$ & & & & $\begin{array}{l}\text { Rills, water flow, pedestals, gullies, wind-scoured areas, blowouts or } \\
\text { deposition areas, litter movement, bare ground, soil resistance to erosion, } \\
\text { soil loss and compaction layer, litter movement }\end{array}$ \\
\hline$\%$ Plant compositions & $\sqrt{ }$ & & $\sqrt{ }$ & $\sqrt{ }$ & & $\sqrt{ }$ & $\begin{array}{l}\text { Annual production, plant mortality, function groups, plant communities, } \\
\text { invasive plants, reproductive capability }\end{array}$ \\
\hline$\%$ Functional groups & $\sqrt{ }$ & & $\sqrt{ }$ & $\sqrt{ }$ & & $\sqrt{ }$ & $\begin{array}{l}\text { Soil resistance to erosion, soil loss, compaction layer, plant mortality, } \\
\text { litter amount, annual production, plant mortality, litter amount, } \\
\text { productivity, invasive plants, reproductive capability of perennial plants }\end{array}$ \\
\hline$\%$ Lichen & $\sqrt{ }$ & $\sqrt{ }$ & $\sqrt{ }$ & $\sqrt{ }$ & $\sqrt{ }$ & $\sqrt{ }$ & Biological soil crusts distribution and degree of development \\
\hline \% Moss & $\sqrt{ }$ & $\sqrt{ }$ & $\sqrt{ }$ & $\sqrt{ }$ & $\sqrt{ }$ & $\sqrt{ }$ & Biological soil crusts distribution and degree of development \\
\hline$\%$ Grass cover & $\sqrt{ }$ & & $\sqrt{ }$ & $\sqrt{ }$ & $\sqrt{ }$ & & $\begin{array}{l}\text { Above ground production, water flow, soil surface loss, soil resistance to } \\
\text { erosion, compaction layer, litter movement }\end{array}$ \\
\hline
\end{tabular}

According to Elmarsdottir et al. (2003), application of fertilizer without additional seeding on degraded lands can enhance favourable microsite availability and the turnover of native species, and expand plants cover. Site treatments such as seeding, planting turfs, fertilizing, organic mulching or soils physical treatment were known to accelerate succession by improving biotic and abiotic conditions of degraded lands (Aronson et al., 2006; Prach \& Hobbs 2008; Řehounková \& Prach, 2008; Aradottir, 2012).

Sustainability of the restored area depends on the recovering of the biotic integrity, hydrological functions and soil stability (Herrick et al., 2012). These attributes are the foundation of resilience; i.e. the capacity of the site to recover after perturbation (Holling, 1973). The simple quantitative indicators can be measured as surrogates to the attributes of resilience and the rangeland indicators health (RHI) (Pellant et al., 2005; Riginos \& Herrick, 2010; Kachergis et al., 2011) (Table 1). Biotic integrity as surrogate to energy capture and nutrient cycling can be simply measured by cover of plants, lichen and moss, soil carbon and nitrogen contents, etc.; hydrological functions can be simply measured by cover of bare ground, rocks, basal gaps etc.; soil stability can be estimated by plants cover, litter distribution, soil carbon and nitrogen contents, etc. Therefore, restored area with high cover of vascular plants, lichen and moss and high contents of nitrogen and carbon has a great biotic integrity. These also infer low bare ground, basal gaps and rocks which address improved hydrological functions and soil stability. Some of the indicators can act for more than one attribute, e.g. degraded area with a high cover of bare ground allows water flow and soil loss, which reflects low foliar cover and infer reduced soil stability and biotic integrity. Accordingly, the quantitative indicators can be assessed to address nearby ecosystem functions. This information may probably include biodiversity, plants mortality, soil condition, nutrient and energy fluxes, etc. that are likely to address future changes. Herrick et al. (2012) suggested to use those simple indicators, which reflect both earlier and future changes to monitor short and long term effects of management. These informations could be extrapolated to a large area, by using remote sensing and Geographic Information System (GIS) tools. Such simple indicators were needed for assessment and monitoring land management because they can act for more than one attributes of ecosystems and cover a large landscape (Ludwig et al., 2004). Temporal measurements of these indicators can also be stocked in a data base, integrated in conceptual models such as 
state and transition model $(\mathrm{S} \& \mathrm{~T}$ ) to guide lands management by identifying thresholds and trends, and adjusting strategies (Karl \& Herrick, 2010).

\subsection{Comparison of the two Monitoring Protocols}

Similar trends were observed in the recovery of the restored areas when data from monitoring protocols were analysed separately. Both protocols showed greater plants foliar cover and base, functional groups abundance, soil carbon and nitrogen contents and $\mathrm{C} / \mathrm{N}$ ratio and lower bare ground, rocks, plants basal gaps and soil $\mathrm{pH}$ at the restored areas. Consequently, the indicators revealed the gradual improvement of the ecological condition of the restored areas, which is better at the old restoration area than at the young restored area. Analysis of the pooled data showed variations of assessment data between the three treatments, samples and the two methods despite the surveying of the same areas. These variations could be attributed to the difference of the data provided by the two protocols. Compared to modified Braun-Blanquet, the stick method gave lower cover of bare ground while modified Braun-Blanquet tended to give lower cover of total plants, litter, moss shrub, forb, grass, lichen, and litter (Figure 4). This variation could be also attributed to the difference of the sampling locations at the same pre-determined point, but variation between protocols and plots could be more important than between surveying locations (Anderson \& Fehmi, 2005). Moreover plants were recognized to have spatial patterns than being distributed uniformly. In fact, changes in surveying location could allow change in vegetation data in the same plants community (Carlsson et al., 2005). Observer behaviour in placing the sample and the rod, following the transect, and ocular estimation level (Tonteri, 1990) could also affect the data. Experience of the observer in vegetation sampling has been shown to improve the accuracy of the data (Kercher et al., 2003; Carlsson et al., 2005; Milberg et al., 2008).

As the two protocols provided similar tendencies, they led to a comparable interpretation of the data. Hence, the differences observed should be considered as bias that could be linked to the differences between the two protocols and the spatial variability of the vegetation. These factors could interact and influence the precision of the data. Studies to compare the accuracy of ocular estimation of cover such as modified Braun-Blanquet, Daubenmire and modified Whittaker plots, etc to other methods of surveying vegetation (Kercher et al., 2003; Leis et al., 2003; Anderson \& Fehmi, 2005; Godínez-Alvarez et al., 2009; Laliberté et al., 2010) have shown that ocular estimation can lower estimate plants cover, but it seems to have great potential to detect maximum species number of assessing areas compared to the line-point intercept. Consequently, ocular estimates methods seem to be good to monitor and assess biodiversity (Stohlgren et al., 1998; Godínez-Alvarez et al., 2009). Ocular estimates methods also seem to be consistent for assessing shrub cover than line-point intercept protocol (Brun \& Box, 1963; Floyd \& Anderson, 1987). Godínez-Alvarez et al. (2009) supported to use ocular estimates method to assess vegetation dominates by shrubs. The stick method is a modification of line-point intercept. Compared to ocular estimations methods, line-point intercept seems to be more precise to measure foliar cover (Godínez-Alvarez et al., 2009; Kercher et al., 2003). Accordingly, the stick method may also be more accurate to estimate cover of vascular plants, lichen, moss, rocks and litter than modified Braun-Blanquet. It provided three supplementary indicators which were not available by modified Braun-Blanquet: basal and canopy gaps, and plants base that are related to wind and water erosion, and infer hydrological functions, biotic integrity and soil stability. It is also a science-based monitoring protocol that can be simply used by local communities without assistance (Riginos \& Herrick, 2010), which makes it very useful in land assessment as in the "Farmers Heal the Land" project. Other observations to be proved by further studies, stick method seem to be more economic in time than modified Braun-Blanquet.

\section{Conclusion and Recommendation}

The main purpose of land management assessment and monitoring is to provide indicators that can reliably assess the condition of the land. The investigation showed that the two assessing protocols provide the same tendency. The estimate indicators can be related to the three attributes of ecosystems that include soil stability, hydrological functions and biotic integrity, and the indicators of rangeland health. The information from the two protocols could be extrapolated to a large area using remote sensing and GIS tools. The results can also be integrated in conceptual models such as S \& T models to identify management trends, thresholds for the control of the management. This study revealed the robustness of the two protocols to assess and monitor land management. Compared to the modified Braun-Blanquet, the stick method seems to estimate greater cover of vascular plants, moss, litter and rocks. The two protocols provide similar estimates cover of lichen and sedge. In spite of that, the stick method may better assess lands condition and monitor revegetated lands because it also provides supplementary indicators like plants base, basal and canopy gaps that are not provided by modified Braun-Blanquet protocol. 


\section{Acknowledgements}

This paper is a part of my final report of the United Nation University-Land Restoration Training programme (UNU-LRT), I would like to acknowledge the UNU-LRT programme, the Soil Conservation Service of Iceland and the "Institut National de la Recherche Agronomique du Niger" for having allowed me to attend this training.

\section{References}

Anderson, A. B., \& Fehmi, J. S. (2005). Comparison of Two Survey Methods for Estimating vegetative Cover. Transactions of the Illinois State Academy of Science, 97, 165-178.

Aradottir, A. L., Robertson, A., \& Moore, E. (1997). Circular statistical analysis of birch colonization and the directional growth response of birch and black cottonwood in south Iceland. Agricultural and Forest Meteorology, 84, 179-186. http://dx.doi.org/10.1016/s0168-1923(96)02385-4

Aradottir, A. L. (2005). Restoration of birch and willow woodland on eroded areas. Proceedings of the AFFORNORD conference on Effects of afforestation on ecosystems, landscape and rural development. Reykholt, Iceland, June 18-22, 2005. Nordic Council, Copenhagen.

Aradottir, A. L. (2012). Turf transplants for restoration of alpine vegetation: does size matter? Journal of Applied Ecology, 49, 439-446. http://dx.doi.org/10.1111/j.1365-2664.2012.02123.x

Aradottir, A. L., \& Oskarsdottir, G. (2013). The use of native turf transplants for roadside revegetation in a subarctic area. Icelandic Agricultural Sciences, 26, 59-67.

Aradottir, A. L., \& Hagen, D. (2013). Ecological Restoration: Approaches and Impacts on Vegetation, Soils and Society. Advances in Agronomy, 120, 173-222. http://dx.doi.org/10.1016/b978-0-12-407686-0.00003-8.

Arnalds, O. (2000). Desertification: an appeal for a broader perspective. In Rangeland desertification. In O. Arnalds \& S. Archer (Eds.), Kluwer Academic Dordrecht/Boston/London (pp. 5-15).

Arnalds, O., Thorarinsdottir, E. F., Metusalemsson, S., Jonsson, A., Gretarsson, E., \& Arnason, A. (2001). Soil erosion in Iceland. Soil Conservation Service and Agriculture Research Institute of Iceland.

Arnalds, O., Orradottir, B., \& Aradottir, A. L. (2013). Carbon accumulation in Icelandic desert Andosols during early stages of restoration. Geoderma, 193, 172-179. http://dx.doi.org/10.1016/j.geoderma.2012.10.018.

Aronson, J., Clewell, A. F., Blignaut, J. N., \& Milton, S. J. (2006). Ecological restoration: A new frontier for nature conservation and economics. Journal for Nature Conservation, 14, 135-139. http://dx.doi.org/10.1016/j.jnc.2006.05.005

Aronson, J.C Floret, E Floc'h, C Ovalle and R Pontanier (1993). Restoration and Rehabilitation of Degraded Ecosystems in Arid and Semi-Arid Lands. I. A View from the South. Restoration Ecology, 1, 8-17. http://dx.doi.org/10.1111/j.1526-100X.1993.tb00004.x

Blakemore, I. C, Searle, P. L., \& Daly, B. K. (1972). Methods of Chemical Analysis of Soils. New Zealand Soil Bureau Report 10A. Government Printer, Wellington, New Zealand. Retrieved from http://digitallibrary.landcareresearch.co.nz/cdm/ref/collection/p20022coll2/id/139

Bestelmeyer, B. T, Tugel, A. J., Peacock Jr, G. L., Robinett, D. G., Shaver, P. L., Brown, J. R., ... Havstad, K. M. (2009). State-and-transition models for heterogeneous landscapes: a strategy for development and application. Rangeland Ecology \& Management, 62, 1-15.

Bonham, C. D., Mergen, D. E., \& Montoya, S. (2004). Plant cover estimation: a contiguous Daubenmire frame. Rangeland Ecology \& Management, 26, 17-22. http://dx.doi.org/10.2111/RANGELANDS-D-10-00077.1

Brun, J. M., \& Box, T. W. (1963). A comparison of line intercepts and random point frames for sampling desert shrub vegetation. Journal of Range Management, 16, 21-25.

Cairns Jr, J., \& Heckman, J. R. (1996). Restoration ecology: the state of an emerging field. Annual Review of Energy and the Environment, 21, 167-189. http://dx.doi.org/10.1146/annurev.energy.21.1.167

Callaway, R. M., \& Walker, L. R. (1997). Competition and facilitation: a synthetic approach to interactions in plant communities. Ecology, 78, 1958-1965. http://dx.doi.org/10.1890/0012-9658(1997)078

Carlsson, A. L., Bergfur, M. J., \& Milberg, P. (2005). Comparison of data from two vegetation monitoring methods in semi-natural grasslands. Environmental Monitoring and Assessment, 100, 235-248.

Clements, F. E. (1936). Nature and structure of the climax. Journal of Ecology, 24, 252-284. 
Connell, J. H., \& Slatyer, R. O. (1977). Mechanisms of succession in natural communities and their role in community stability and organization. American Naturalist, 1119-1144. Retrieved from https://www.jstor.org/stable/2460259

Daubenmire, R. F. (1959). A canopy -cover method of vegetational analysis. Northwest Science, 33, 43-46.

Day, R., \& Quinn, G. (1989). Comparisons of treatments after an analysis of variance in ecology. Ecological Monographs, 59, 433-463. http://dx.doi.org/10.2307/1943075/full

Del Moral, R., Saura, J. M., \& Emenegger, J. N. (2010). Primary succession trajectories on a barren plain, Mount St. Helens, Washington. Journal of Vegetation Science, 21, 857-867. http://dx.doi.org/10.1111/j.1654-1103.2010.01189.x

Dudley, N., Morrison, J., Aronson, J., \& Mansourian, S. (2005). Why Do We Need to Consider Restoration in a Landscape Context? In S. Mansourian, D. Vallauri \& N. Dudley (eds.), Forest Restoration in Landscapes: Beyond Planting Trees (pp. 51-58). Springer, New York (USA).

Dytham, C. (2011). Choosing and using statistics: a biologist's guide. Wiley-Blackwell Malden, MA, USA.

Egler, F. E. (1954). Philosophical and practical considerations of the Braun-Blanquet system of phytosociology. Castanea, 19, 45-60. http://dx.doi.org/10.2307/20165286/pdf

Elmarsdottir, A., Aradottir, A. L., \& Trlica, M. (2003). Microsite availability and establishment of native species on degraded and reclaimed sites. Journal of Applied Ecology, 40, 815-823. http://dx.doi.org/10.1046/j.1365-2664.2003.00848.x

Emery, S. M., \& Rudgers, J. A. (2010). Ecological assessment of dune restorations in the great lakes region. Restoration Ecology, 18, 184-194. http://dx.doi.org/10.1111/j.1526-100X.2009.00609.x

Floyd, D. A., \& Anderson, J. E. (1987). A comparison of three methods for estimating plant cover. The Journal of Ecology, 221-228. http://www.jstor.org/stable/2260547

Fukami, T., \& Nakajima, M. (2011). Community assembly: alternative stable states or alternative transient states?. Ecology letters, 14, 973-984. http://dx.doi.org/10.1111/j.1461-0248.2011.01663.x

Galatowitsch, S. M. (2012). Ecological restoration. Sinauer Associates, Sunderland, Massachusetts USA. http://dx.doi.org/10.1002/jwmg.747/abstract

Gleason, H. A. (1917). The structure and development of the plant association. Bulletin of the Torrey Botanical Club, 44, 463-481.

Godínez-Alvarez, H., Herrick, J., Mattocks, M., Toledo, D., \& Van Zee, J. (2009). Comparison of three vegetation monitoring methods: their relative utility for ecological assessment and monitoring. Ecological Indicators, 9, 1001-1008.

Gretarsdottir, J., Aradottir, A. L, Vandvik, V., Heegaard, E., \& Birks, H. (2004). Long-Term Effects of Reclamation Treatments on Plant Succession in Iceland. Restoration Ecology, 12, 268-278. http://dx.doi.org/10.1111/j.1061-2971.2004.00371.x.

Gunnlaugsdottir, E. (1985). Composition and dynamical status of heathland communities in Iceland in relation to recovery measure. Acta Phytogeographica Suecica, 75, Uppsala, Sweden. http://dx.doi.org/10.1111/j.1756-1051.1987.tb00930.x/abstract

Havstad, K., \& Herrick, J. (2003). Long-term ecological monitoring. Arid Land Research and Management, 17, 389-400. http://dx.doi.org/10.1080/713936102

Herrick, J, Bestelmeyer, B., Archer, S, Tugel, A., \& Brown, J. (2006). An integrated framework for science-based arid land management. Journal of Arid Environments, 65, 319-335.

Herrick, J. E., Urama, K. C., Karl, J. W., Boos, J., Johnson, M. V. V., Shepherd, K. D., ... Guerra, J. L. (2013). The global Land-Potential Knowledge System (LandPKS): Supporting evidence-based, site-specific land use and management through cloud computing, mobile applications, and crowdsourcing. Journal of Soil and Water Conservation, 68, 5A-12A. http://dx.doi.org/10.2489/jswc.68.1.5A

Herrick, J. E., Duniway, M. C., Pyke, D. A., Bestelmeyer, B. T., Wills, S. A., Brown, J. R., ... Havstad, K. M. (2012). A holistic strategy for adaptive land management. Journal of Soil and Water Conservation, 67, 105-113. http://dx.doi.org/10.2489/jswc.67.4.105A

Herrick, J. E., Justin, W., Van Zee, K., Havstad, M., Burkett, L. M., \& Whitford, W. G. (2005). Monitoring manual for grassland, shrubland and savanna ecosystems. Vol. II: Design, supplementary methods and 
interpretation. Jornada Experimental Range, Las Cruces, NM: Distributed by University of Arizona Press., Arizona press. Retrieved from http://jornada.nmsu.edu/monit-assess/manuals

Herrick, J. E., Schuman, G. E., \& Rango, A. (2006). Monitoring ecological processes for restoration projects. Journal for Nature Conservation, 14(3), 161-171.

Hobbs, R. J., \& Cramer, V. A. (2008). Restoration ecology: interventionist approaches for restoring and maintaining ecosystem function in the face of rapid environmental change. Annual Review of Environment and Resources, 33, 39-61. http://dx.doi.org/10.1146/annurev.environ.33.020107.113631

Hobbs, R. J., \& Norton, D. A. (2004). Ecological filters, thresholds, and gradients in resistance to ecosystem reassembly. In Assembly rules and restoration ecology: Bringing the gap between theory and pratice. In V. M. Temperton, R. J. Hobbs, T. Nuttle \& S. Halle (Eds), Island Press, Washington, DC (USA), 72-95. Retrieved from http://research-repository.uwa.edu.au

Holling, C. S. (1973). Resilience and stability of ecological systems. Annual Review of Ecology and Systematics, 4, 1-23. http://dx.doi.org/10.1146/annurev.es.04.110173.000245

Howell, E. A., Harrington, J. A., \& Glass, S. B. (2012). Introduction to restoration ecology. Washington DC, USA: Island Press.

Kachergis, E., Rocca, M. E., \& Fernandez-Gimenez, M. E. (2011). Indicators of ecosystem function identify alternate states in the sagebrush steppe. Ecological applications, 21, 2781-2792. http://warnercnr.colostate.edu

Karl, J. W., \& Herrick, J. E. (2010). Monitoring and assessment based on ecological sites. Rangelands Ecology and Management, 32, 60-64. http://dx.doi.org/10.2111/RANGELANDS-D-10-00082.1

Karlsdóttir, L., \& Aradóttir, Á. L. (2006). Propagation of Dryas octopetala L. and Alchemilla alpina L. by direct seedling and planting of stem cuttings. Icelandic Agricultural Sciences, 19, 25-32.

Kercher, S. M., Frieswyk, C. B., \& Zedler, J. B. (2003). Effects of sampling teams and estimation methods on the assessment of plant cover. Journal of Vegetation Science, 14(6), 899-906.

Lal, R. (2004). Soil carbon sequestration impacts on global climate change and food security. Science, 304(5677), 1623-1627.

Lal, R. (2004). Soil carbon sequestration to mitigate climate change. Geoderma, 123(1), 1-22.

Laliberté, E., Norton, D. A., Tylianakis, J. M., \& Scott, D. (2010). Comparison of two sampling methods for quantifying changes in vegetation composition under rangeland development. Rangeland ecology \& management, 63(5), 537-545.

Leis, S. A. (2015, February). Comparison of vegetation sampling procedures in a disturbed mixed-grass prairie. In Proceedings of the Oklahoma Academy of Science (Vol. 83, pp. 7-15).

Ludwig, J. A., Tongway, D. J., Bastin, G. N., \& James, C. D. (2004). Monitoring ecological indicators of rangeland functional integrity and their relation to biodiversity at local to regional scales. Austral ecology, 29(1), 108-120.

McCune, B. P., \& Grace, J. B. (2002). Analysis of ecological communities. MJM software design, Gleneden beach, Oregon, USA.

MEA. (2005). Millenium Ecosystem Assessment. Ecosystems and Human Well-being: Biodiversity Synthesis. World Resources Institute, Washington DC, USA.

Milberg, P., Bergstedt, J., Fridman, J., Odell, G., \& Westerberg, L. (2008). Observer bias and random variation in vegetation monitoring data. Journal of Vegetation Science, 19(5), 633-644.

Miller, M. E. (2008). Broad-scale assessment of rangeland health, Grand Staircase-Escalante National Monument, USA. Rangeland Ecology \& Management, $259-262$. www.bioone.org/doi/pdf/10.2111/07-107.1

Odum, E. P. (1969). The strategy of ecosystem developement. Science, 64, 262-270.

Palmer, M., Allan, J. D., Meyer, J., \& Bernhardt, E. S. (2007). River restoration in the twenty - first century: data and experiential knowledge to inform future efforts. Restoration Ecology, 15(3), 472-481. 
Parker, V. T., \& Pickett, S. T. (1997). Restoration as an ecosystem process: implications of the modern ecological paradigm. In K. M. Urbanska, N. R. Webb \& P. J. Edwards (eds.), Restoration Ecology and Sustainable Development (pp. 17-32). Cambridge University Press, Cambridge.

Pellant, M., Shaver, P., Pyke, D. A., \& Herrick, J. E. (2000). Interpreting indicators of rangeland health, version 3. Technical Reference 1734-6. U.S. Department of the Interior, Bureau of Land Management, National Science and Technology Center, Denver, CO. BLM/WO/ST-00/001+1734/REV05. Retrieved from http://jornada.nmsu.edu/monit-assess/manuals

Pellant, M., Shaver, P., Pyke, D. A., \& Herrick, J. E. (2005). Interpreting indicators of rangeland health, version 4. Technical Reference 1734-6. U.S., Department of the Interior, Bureau of Land Management, National Science and Technology Center, Denver, CO. BLM/WO/ST-00/001+1734/REV05. Retrieved from http://jornada.nmsu.edu/monit-assess/manuals

Petursdottir, T., Aradottir, A. L., \& Benediktsson, K. (2013). An Evaluation of the Short - Term Progress of Restoration Combining Ecological Assessment and Public Perception. Restoration Ecology, 21(1), 75-85. http://dx.doi.org/10.1111/j.1526-100X.2011.00855.x.

Pickett, S. T. A., Collins, S. L., \& Armesto, J. J. (1987). Models, mechanisms and pathways of succession. The Botanical Review, 53(3), 335-371.

Prach, K, Marrs, R., Pyšsek, P., \& Van Diggelen, R. (2007). Manipulation of succession. In L. R. Walker, J. Walker \& R. Hobbs (Eds.), Linking ecological restoration and ecological succession (pp. 121-149). Springer, New York (USA).

Prach, K., \& Hobbs, R. J. (2008). Spontaneous succession versus technical reclamation in the restoration of disturbed sites. Restoration Ecology, 16, 363-366.

Prosser, C. W., Skinner, K. M., \& Sedivec, K. K. (2003). Comparison of 2 techniques for monitoring vegetation on military lands. Journal of Range Management, 446-454.

Raevel, V., Violle, C., \& Munoz, F. (2012). Mechanisms of ecological succession: insights from plant functional strategies. Oikos, $121(11), 1761-1770$.

Řehounková, K., \& Prach, K. (2008). Spontaneous vegetation succession in gravel-sand pits: a potential for restoration. Restoration Ecology, 16(2), 305-312.

Riginos, C., \& Herrick, J. E. (2010). Monitoring Rangeland Health: A Guide for Pastoralist Communities and Other Land Managers in Eastern Africa, Version II, Nairobi, Kenya: ELMT-USAID/East Africa.

Ruiz-Jaen, M. C., \& Mitchell Aide, T. (2005). Restoration success: how is it being measured? Restoration Ecology, 13(3), 569-577. http://dx.doi.org/10.1111/j.1526-100X.2005.00072.x

SER. (2004). Society for Ecological Restoration International Science \& Policy Working Group. The SER International Primer on Ecological Restoration. Tucson, Arizona, USA. Retrieved from http://www.ser.org/resources/resources-detail-view/ser-international-primer-onecological-restoration

Sheley, R. L., James, J. J., Vasquez, E. A., \& Svejcar, T. J. (2011). Using rangeland health assessment to inform successional management. Invasive Plant Science and Management, 4(3), 356-366.

Silver, W. L., Ostertag, R., \& Lugo, A. E. (2000). The potential for carbon sequestration through reforestation of abandoned tropical agricultural and pasture lands. Restoration ecology, 8(4), 394-407.

Steen, D. A., Conner, L. M., Smith, L. L., Provencher, L., Hiers, J. K., Pokswinski, S., ... Guyer, C. (2013). Bird assemblage response to restoration of fire - suppressed longleaf pine sandhills. Ecological Applications, 23(1), 134-147.

Steen, D. A., Smith, L. L., Conner, L. M., Litt, A. R., Provencher, L., Hiers, J. K., ... Guyer, C. (2013). Reptile assemblage response to restoration of fire-suppressed longleaf pine sandhills. Ecological Applications, 23(1), 148-158.

Stohlgren, T. J., Bull, K. A., \& Otsuki, Y. (1998). Comparison of rangeland vegetation sampling techniques in the Central Grasslands. Journal of Range Management, 164-172.

Suding, K. N., Gross, K. L., \& Houseman, G. R. (2004). Alternative states and positive feedbacks in restoration ecology. Trends in Ecology \& Evolution, 19(1), 46-53. 
Toevs, G. R., Karl, J. W., Taylor, J. J., Spurrier, C. S., Karl, M. S., Bobo, M. R., \& Herrick, J. E. (2011). Consistent indicators and methods and a scalable sample design to meet assessment, inventory, and monitoring information needs across scales. Rangelands, 33(4), 14-20.

Tongway, D. J., \& Hindley, N. L. (2004). Landscape function analysis manual: procedures for monitoring and assessing landscapes with special reference to minesites and rangelands. CSIRO Sustainable Ecosystems Canberra, ACT. Retrieved from http://www.cse.csiro.au

Tonteri, T. (1990). Inter-observer variation in forest vegetation cover assessments. Silva Fennica, 24, 189-196.

UNEP (2002). United Nations Environment Programme. Report of the sixth meeting of the conference of the parties to the Convention on Biological Diversity (UNEP/CBD/COP/6/20). Decision VI/26, UNEP. Retrieved from http://www.biodiv.org/decisions/?mZcop-06/

Van Der Maarel, E. (1979). Transformation of cover-abundance values in phytosociology and its effects on community similarity. Vegetation, 39, 97-114.

Walker, L. R., Bellingham, P. J., \& Peltzer, D. A. (2006). Plant characteristics are poor predictors of microsite colonization during the first two years of primary succession. Journal of Vegetation Science, 17(3), 397-406.

Walker, L. R., \& del Moral, R. (2003). Primary succession and ecosystem rehabilitation. Cambridge University Press, New York, USA. http://dx.doi.org/10.1017/CBO9780511615078

Walker, L. R., \& del Moral, R. (2008). Transition dynamics in succession: implications for rates, trajectories and restoration. In K. Suding \& R. J. Hobbs (eds), New Models for Ecosystem Dynamics and Restoration (pp. 33-50). Island Press, Washington DC, USA.

Walker, L. R., \& del Moral, R. (2009). Lessons from primary succession for restoration of severely damaged habitats. Applied Vegetation Science, 12, 55-67.

Walker, L. R., Walker, J., \& del Moral, R. (2007). Forging a new alliance between succession and restoration. In L. R. Walker, J. Walker \& R. Hobbs (eds.), Linking ecological restoration and ecological succession (pp. 1-18). Springer, New York, USA. Retrieved from http://www1.inecol.edu.mx/repara/download

Werger, M. (1974). The place of the Zürich-Montpellier method in vegetation science. Folia Geobotanica et Phytotaxonomica, 9, 99-109. http://www.jstor.org/stable/4179782

Whisenant, S. (1999). Repairing damaged wildlands: a process-orientated, landscape-scale approach. Cambridge University Press, New York, USA. http://dx.doi.org/10.1017/CBO9780511612565

Yates, C. J., \& Hobbs, R. J. (1997). Woodland restoration in the Western Australian wheatbelt: a conceptual framework using a state and transition model. Restoration Ecology, 5, 28-35. http://dx.doi.org/10.1046/j.1526-100X.1997.09703.x

\section{Copyrights}

Copyright for this article is retained by the author(s), with first publication rights granted to the journal.

This is an open-access article distributed under the terms and conditions of the Creative Commons Attribution license (http://creativecommons.org/licenses/by/3.0/). 